\title{
Estimation of some Elements and Acids for the Different Grape Juice
}

\author{
Dalia M. Jamil \\ Department of Chemistry, Collage of Science, Al -Nahrain University, Baghdad-Iraq. \\ Corresponding Author: daliamahmood34@yahoo.com.
}

\begin{abstract}
This study included estimating the heavy elements of some types of grape juice of different origin and determining their proportions in juices and comparing them with the quality control of Iraq and observing whether it is suitable for human use or not. Calcium salts are observed as $137 \mathrm{ppm}$ in $\mathrm{C}$ juice and $9.5 \mathrm{ppm}$ of magnesium in juice $\mathrm{B}$, for heavy metals the highest percentage of lead $0.19 \mathrm{ppm}$ recorded in juice A, $1.7 \mathrm{ppm}$ of copper in B juice $3.5 \mathrm{ppm}$ Iron in juice A, $0.8 \mathrm{ppm}$ of zinc in $\mathrm{B}$ juice and $\mathrm{A}, 0.06 \mathrm{ppm}$ of aluminum in $\mathrm{B}, 0.015 \mathrm{ppm}$ of cobalt in juice $\mathrm{A}$ and $\mathrm{B}$, $0.06 \mathrm{ppm}$ of nickel in B juice, Sodium was $168.1 \mathrm{ppm}$ in $\mathrm{C}$ juice, but the acids were found to have the highest rates were $3.1 \mathrm{ppm}$ of malic acid in B, $156.7 \mathrm{ppm}$ of acid in Juice of ascorbic B, $238.5 \mathrm{ppm}$ of acid found in lemon juice 130ppm in juice B. [DOI: 10.22401/JUNS.21.1.04]
\end{abstract}

Keywords: grape juice, Food additives, Heavy metals, Organic acids, Atomic absorption, Titration Chemistry, $\mathrm{pH}$

\section{Introduction}

Grapes are containing phenolic compounds that, this important for development products derived from grape, and also this health effect. This study is evaluating juice commercial, result metals from these juices [1]. That notice show in the special red grape product, is rich phenol compounds [2]. Phenol compound important not only because of this important function for development of grape product, but another also health effect [3]. Commercial fruit juices (apples, peaches, apricots, oranges, kiwi, pear, pineapple, and multiple fruits) were examined from heavy metal and mineral content point. And exceeded the values obtained from the limits imposed by these international organizations. The concentrations of the company, copper, zinc and olives were down of the acceptable drinking water level for all samples, while the concentrations of nickel with lead, the limits imposed by the US Environmental Protection Agency and the World Health Organization on fruit juices. That's include the study is similar to this in literature [4].

The presence of impurities and foreign to human amortization because they present health dangerouss when they outstrip limits. The juices need special attention in purity and the sources of water and purification are crucial for maintaining quality and safety [5]. Many flavonoids in grape juice, like catechin, epicatechin and anthocyanins containe antioxidant, anti-inflammatory, and platelet inhibitor effects, thats could to decrease LDL oxidation and oxidative damage to DNA, in animal studies [6]. Grape is rich in phenol compounds that have attention not only because important in development products from grape, but also health effects. this study is to estimate commercial grape juices produced. Grape juice is analyzed phenolic content, colour, and antioxidant activity. The commercial juice was the large curve values for total monomeric anthocyanins with total phenolic. This is positive correlation $(\mathrm{R}=0.9566)$ between the antioxidant activity and total phenolic content of commercial juice. In addition, the Component Analysis explains strong positive relation between red color and total monomeric anthocyanins [7]. The favorite the correlation between trace element, total antioxidant capacity, total phenolic content, hystamine concentrations of grape [8]. Simple sample preparation technique in grape analysis is UV-photolysis that allows low blanks with minimal analyte losses [9-10]. Other nontoxic samples that benefiters when present in amounts not encroaching 100 ppm include $\mathrm{Al}, \mathrm{B}, \mathrm{Cr}, \mathrm{Ni}$ and $\mathrm{Sn}$ [11].

The some metals used to identify the geographic region in of the grapes were development due to the direct relationship with soil synthesis [12-13]. 


\section{Materials and Methods}

This experiment was conducted different samples of grape juice from Baghdad for the month of Aprile. To determine the element by analyzing for acids with trace metals in grape juices for different markers. The samples were analyzed was 10 for each type (original metal cans, and Original and dalia Carboard can). The kinds of impurities found in grape juice in the markets should be pinnacled. It shoud be forcing the producers to change their methods of production. [14].

\section{Acid Determination}

The acidity of this juice is determined by titrate a known volume of juice with a standard solution from $\mathrm{NaOH}$ with phenonaphthalein as indicator.

$\mathrm{pH}$ is determined using an electronic $\mathrm{pH}$ meter (Crison, model Micro pH 2002, S.A., Barcelona, Spain), and acidity by titration with $\mathrm{NaOH} 0.1 \mathrm{M}$ [15]. Chemical analysis for different samples in according with standard methods followed by-:

1.Mixing sample by food mixer then become spontaneous. Drying for samples juice in the furnace at $25^{\circ} \mathrm{C}$ for determines the percentage of steaminess for samples. Then grind the dry sample by mortar that becomes for metals analysis, then keep after.

2.Measure the acidity by $\mathrm{PH}$ for all grape juice and measure acidity.

3.Grind in poly ethylene bags with identification cards for all pieces.

4.Put $1 \mathrm{~g}$ from sample to $550^{\circ} \mathrm{C}$ in heater, then added $\mathrm{HCl}(2 \mathrm{M})$ and complete the volume to $50 \mathrm{ml}$ by using $0.1 \mathrm{M} \mathrm{HCl}$, then can be measured [16].

Estimate the samples by using atomic absorption spectrophotometer, the study consist three types of grape juice according to Table (1).

Table (1)

Type of Orange Juice, Original and Capacity.

\begin{tabular}{||c||c||c||}
\hline Type & Original & Capacity \\
\hline \hline $\begin{array}{c}\text { Metal cans } \\
\text { Original }\end{array}$ & $\begin{array}{c}\text { Saudi Arabia } \\
\text { (KSA) }\end{array}$ & $240 \mathrm{ml}$ \\
\hline $\begin{array}{c}\text { Cardboard } \\
\text { Cans Original }\end{array}$ & $\begin{array}{c}\text { Saudi Arabia } \\
\text { (KSA) }\end{array}$ & $250 \mathrm{ml}$ \\
\hline \hline $\begin{array}{c}\text { Cardboard } \\
\text { cans Dalya }\end{array}$ & Kuait & $250 \mathrm{ml}$ \\
\hline
\end{tabular}

\section{Determination of Heavy Metals}

The metals were measured with a PerkinElmer model 2380 Atomic Absorption Spectrometer, double beam and deuterium background correction.

Cathode lamps of $\mathrm{Pb}, \mathrm{Cd}$ and $\mathrm{Co}$ wave measured for all metals.

Measurements were operated against metal standard solutions [17].

This quantitatively determines the synthesis of heavy metals like $\mathrm{Pb}, \mathrm{Cu}, \mathrm{Ni}, \mathrm{Zn}$ and $\mathrm{Fe}$ in 24 different samples. Analysis of these samples in the presence of heavy metals were determine by using Atomic Absorption Spectrophotoscopy (AAS). That's

show high level of heavy metals, although the legal limits [18].

\section{Result and Discussion}

Results showed Entries in the Table (2) that there are differences in acid, all of which are $\mathrm{pH}$ that Malic acid and ascorbic acid for all types of juices under study where the $\mathrm{pH}$ in the juice (B) higher values $3.7 \mathrm{ppm}$ and thus was the approach to Asaran $\mathrm{A}$ and $\mathrm{C}$ were all within the Iraqi specification [19] did not exceed the value is ( $3.7 \mathrm{ppm})$. As for malic acid highest values of the rates recorded in the juice (A) is (3.1ppm) as well as all of the $B$ and $\mathrm{C}$ record (3.3-2.7ppm), respectively, and are these values are not permitted within the Iraqi standard quality of the product, while Ascorbic acid recorded values allowed within the specification of Iraq in 1989 and this value (300ppm) in the juice was worth B (165.7ppm) Both juice no record of $\mathrm{A}$ and $\mathrm{C}$ concrete results of this acid, and the Ascorbic acid record high values and all kinds of juices and the highest value in the juice $\mathrm{C}$ was (239.6ppm) which is not within the specification of Iraq in 1989 and for all kinds of juices. With regard to all species except the $\mathrm{pH}$ it was within the permissible in the Iraqi specification limits and thus These results are identical to those stated in [20] in terms of recorded values high acids measured in the juices under study.

As for the mineral salts for each of the saline calcium $\mathrm{CaCl}_{2}$ and magnesium $\mathrm{MgCl}_{2}$ recorded the highest values of the salts of the $\mathrm{CaCl}_{2}$ in juice $\mathrm{C}$ amounted to (137ppm) and all the juices were within the limits of the specification allowed Iraqis and this value 
(300 ppm), while $\mathrm{MgCl} 2$ scored its highest value in the juice $B$ reached $(9.5 \mathrm{ppm})$, juice $A$ $(8.1 \mathrm{ppm})$, and juice $\mathrm{C}(8.0 \mathrm{ppm})$ were all kinds of juices that are not permitted within the boundaries of good product and this value (zero ppm) Iraqi Specification 1989 [21].

The heavy metals were among the Table (2) that the measured elements are $\mathrm{Pb}$, $\mathrm{Cu}, \mathrm{Fe}, \mathrm{Zn}, \mathrm{Al}, \mathrm{Co}, \mathrm{Ni}$, and $\mathrm{Na}$ began the element $\mathrm{Pb}$ has recorded its highest values in the juice A amounted to (0.19ppm) and all kinds of juices were within the Iraqi specification [19] and this value $(0.5 \mathrm{ppm})$ and record copper, according to the Table (2) its highest value in the juice $B$ amounted to (1.7 ppm) and also had all kinds of juices within the Iraqi specification [19] and adult (6.7ppm) $\mathrm{Fe}$ values were recorded the highest ratios in the juice $\mathrm{A}(3.5 \mathrm{ppm})$ and thus be part of a good standard and allowed Iraqis (15ppm). Regarding $\mathrm{Zn}$ highest values he has scored in the juice B $(0.8 \mathrm{ppm})$ were all kinds of juices among others and allowed the border where $(0.2 \mathrm{ppm})$ Iraqis in 1989 , scoring the $\mathrm{Al}$ highest percentages him in sappy $\mathrm{A}$ and $\mathrm{B}$ $(0.015 \mathrm{ppm})$ scored Co highest ratios his juice $\mathrm{B}(0.06 \mathrm{ppm})$ is all of the elements $\mathrm{Al}, \mathrm{Co}, \mathrm{Ni}$ and for all kinds of juices that (1989) (zero $\mathrm{ppm}$ ). And record $\mathrm{Na}$ highest proportions of his juice $\mathrm{C}(168.1 \mathrm{ppm})$ were all kinds of juices within the specification allowed for Iraqis (300 ppm) for the year 1989, the results of the current study was matching with numerous studies in terms of registration and then highest ratios of heavy elements which [22] and [23].

Table (2)

Compare between the standard Iraqi specification and laboratory for orange juice.

\begin{tabular}{|c|c|c|c|c|}
\hline $\begin{array}{c}\text { Examination } \\
\text { Recorder } \\
\end{array}$ & $\begin{array}{c}\text { Orginal (ppm) } \\
(A)\end{array}$ & $\begin{array}{c}\text { Orginal } \\
\text { Cardboard }(\text { ppm })(B) \\
\end{array}$ & $\begin{array}{c}\text { Dalya(ppm) } \\
(C) \\
\end{array}$ & $\begin{array}{c}\text { Standard } \\
\text { specification (ppm) }\end{array}$ \\
\hline $\mathrm{PH}$ & $\begin{array}{c}3.4-3.8 \\
3.6 \\
\end{array}$ & $\begin{array}{c}3.4-3.9 \\
3.7 \\
\end{array}$ & $\begin{array}{c}3.3-3.6 \\
3.8 \\
\end{array}$ & $2.7-3.8$ \\
\hline $\mathrm{CaCl}_{2}$ & $\begin{array}{c}120-130 \\
125 \\
\end{array}$ & $\begin{array}{c}132-138 \\
135 \\
\end{array}$ & $\begin{array}{c}139-135 \\
137 \\
\end{array}$ & 300 \\
\hline $\mathrm{MgCl}_{2}$ & $\begin{array}{c}8.0-8.2 \\
8.1\end{array}$ & $\begin{array}{c}8.5-10.5 \\
9.5\end{array}$ & $\begin{array}{c}7.9-8 \\
8.0 \\
\end{array}$ & - \\
\hline $\mathrm{Pb}$ & $\begin{array}{c}0.18-0.2 \\
0.19 \\
\end{array}$ & $\begin{array}{c}0.08-0.1 \\
0.09 \\
\end{array}$ & $\begin{array}{c}0.02-0.06 \\
0.04 \\
\end{array}$ & 0.3 \\
\hline $\mathrm{Cu}$ & $\begin{array}{c}0.25-0.75 \\
0.5 \\
\end{array}$ & $\begin{array}{c}1.5-1.9 \\
1.7 \\
\end{array}$ & $\begin{array}{c}1.2-1.3 \\
1.3 \\
\end{array}$ & 5 \\
\hline $\mathrm{Fe}$ & $\begin{array}{c}2.7-4.3 \\
3.5 \\
\end{array}$ & $\begin{array}{c}2.2-2.9 \\
2.6 \\
\end{array}$ & $\begin{array}{c}1.9-3.2 \\
2.6 \\
\end{array}$ & 15 \\
\hline $\mathrm{Zn}$ & $\begin{array}{c}0.7-0.9 \\
0.8\end{array}$ & $\begin{array}{c}0.8-0.81 \\
0.8\end{array}$ & $\begin{array}{c}0.02-0.03 \\
0.03\end{array}$ & 0.2 \\
\hline $\mathrm{Al}$ & $\begin{array}{c}0.01-0.02 \\
0.02 \\
\end{array}$ & $\begin{array}{c}0.08-0.04 \\
0.06 \\
\end{array}$ & $\begin{array}{c}0.01-0.002 \\
0.006 \\
\end{array}$ & - \\
\hline $\mathrm{Co}$ & $\begin{array}{c}0.015-0.014 \\
0.015\end{array}$ & $\begin{array}{c}0.017-0.016 \\
0.015\end{array}$ & $\begin{array}{c}0.003-0.004 \\
0.004\end{array}$ & - \\
\hline $\mathrm{Ni}$ & $\begin{array}{c}0.01-0.03 \\
0.02\end{array}$ & $\begin{array}{c}0.05-0.06 \\
0.06 \\
\end{array}$ & $\begin{array}{c}0.002-0.003 \\
0.003 \\
\end{array}$ & $\longrightarrow$ \\
\hline $\mathrm{Na}$ & $\begin{array}{c}138.2-140.3 \\
139.3 \\
\end{array}$ & $\begin{array}{c}157.7-160.7 \\
159.2 \\
\end{array}$ & $\begin{array}{c}169.1-167.2 \\
168.1 \\
\end{array}$ & 300 \\
\hline Malic acid & $\begin{array}{c}2.8-2.9 \\
2.9 \\
\end{array}$ & $\begin{array}{c}2.9-3.3 \\
3.1 \\
\end{array}$ & $\begin{array}{c}2.5-2.9 \\
2.7\end{array}$ & $\begin{array}{l}\text { From best } \\
\text { production }\end{array}$ \\
\hline Ascorbic acid & ------ & $\begin{array}{c}164.5-166.9 \\
165.7 \\
\end{array}$ & $\begin{array}{c}143-184 \\
163.5\end{array}$ & 300 \\
\hline Citric acid & $\begin{array}{c}215-250 \\
232.5\end{array}$ & $\begin{array}{c}234-243 \\
238.5\end{array}$ & $\begin{array}{l}200-210 \\
205\end{array}$ & $\begin{array}{l}\text { From the best } \\
\text { production }\end{array}$ \\
\hline
\end{tabular}




\section{References}

[1] Vívian M., Leila D., Luciano V., Colour, phenolic content and antioxidant activity of grape juice, Ciênc., 30(4), 1027-1032, 2010.

[2] Fuleki T., Ricard M., Effects of cultivar and processing method on the contents of catechins and procyanidins in grape juice, Journal of Agriculture and Food Chemistry, 51, 640-646, 2003.

[3] O'pyrne, D., Comparison of the antioxidant effects of Concord grape juice flavonoids and R-tocopherol on markers of oxidative stress in healthy adults, American Journal of Clinical Nutrition, 76, 1367-1374, 2002.

[4] Adriana D., Dana A., Analysis of Mineral and Heavy Metal Content of Some Commercial Fruit Juices by Inductively Coupled Mass Spectrometry, Hindawi Publishing Corporation The Scientific World Journal, 6, 215423, 2013.

[5] Shabnam M., Parisa Z., Heavy Metal Removal from Commercially-available Fruit Juice Packaged Products by Citric Acid, Oriental Journal of Chemistry, 31 (1), 409-416, 2015.

[6] Singletary K., Inhibition of mammary Tumorigenesis by concord grape juice constituents, Journal of Agriculture and Food Chemistry, 51, 7280-7286, 2003.

[7] Fernandez P., Antioxidant activity of wines and relation with their polyphenolic composition, Analytica Chimica Acta, 513, 113-118, 2004.

[8] Rupasinghe H., Clegg S., Total antioxidant capacity, total phenolic content, mineral elements, and histamine concentrations in wines of different fruit sources, Food Compos. Anal., 20, 133-137, 2007.

[9] Buldini P., Cavalli S., Sharma J., Determination of transition metals in wine by IC, DPASV-DPCSV, and ZGFAAS coupled with UV photolysis, Agric, Food Chem, 47, 1999.

[10] Wierzbicki T., Pyrzynska K. Determination of vanadium content in wine by GF AAS, Chem. Anal.-Warsaw, 47, 449-455, 2002.

[11] Ministry of Health and Family Welfare, Manual of Methods of Analysis of Metals, Government of India, New Delhi, India, 9, 2005.

[12] Barbaste, M., Medina, B., Sarabia, L., Ortiz, M.C. and Perez- Trujillo, J.P.,
Analysis and comparison of SIMCA models for denominations of origin of wines from de Canary Islands (Spain) builds by means of their trace and ultratrace content, Analyt Chim. Acta, 472, 161-174, 2002.

[13] Greenough, J., Mallory-Greenough, L., regional trace element fingerprinting of Canadian wines, Geology and wine Geosci. Can., 32, 229- 137, 2005.

[14] A.O.A.C., Official methods of analysis, Pesticide and Industrial Chemical Residues, A.O.A.C. Int., Arlington, Virginia, USA, $16^{\text {th }}, 1995$.

[15] Oliveira M., Franca A., Microwave heating of foodstuffs, Food Eng 53, 34759, (2002).

[16] Harith, Y., Estimation of Lead in Some of Foods and Drinks Common Popular in Basrah City- Iraq- 2010, Journal of Dialaa for science agriculture, 3(1), 106- 101, (In Arabic), 2011.

[17] AOAC official methods of analysis of AOAC International, 18th edition, AOAC International Gaithersburg, Maryland, USA, 2005.

[18] Priya P., Haware D., Determination of Specific Havanur Heavy Metals in Fruit Juices Using Atomic Absorption Spectroscopy (AAS), International Journal of Research in Chemistry and Environment, 4 (3), 163-168, 2014.

[19] Standard Specification No. (1258) second update, The Ministry of Planing and Development Cooperation, Centeral Oranization for Standerization and Quality Control-Iraq, 1989.

[20] Jain S., Khurdiya D., Vitamin(C) enrichment of fruit juice based ready-toserve beverages through blending of Indian gooseberry (Emblica of ficinalis Gaertn) juice, Plants foods Hum, 59:63, 2005.

[21] USEPA IN tegrated Risk in formation system (IRIS), 2001.

[22] G. Ysart, Food Additives and contaminants, 17(9), 775-786, 2000.

[23] Tufuor J., Bentum J., Koranteng J., Analysis of heavy metals in citrus juice from the Abura- Asebu -Kwamankese District, Ghana. J. Chem. Pharm. Res., 3(2), 397-402, 2011. 